\title{
Expression profile of significant immortalization genes in colon cancer
}

\author{
AGNIESZKA WITKOWSKA ${ }^{1}$, JANUSZ GUMPRECHT ${ }^{1}$, JOANNA GLOGOWSKA-LIGUS ${ }^{2}$, \\ GRZEGORZ WYSTRYCHOWSKI ${ }^{1}$, ALEKSANDER OWCZAREK ${ }^{3}$, MALGORZATA STACHOWICZ ${ }^{2}$, \\ ALINA BOCIANOWSKA ${ }^{2}$, EWA NOWAKOWSKA-ZAJDEL ${ }^{4}$ and URSZULA MAZUREK ${ }^{2}$ \\ Departments of ${ }^{1}$ Internal Medicine, Diabetology and Nephrology, Zabrze, ${ }^{2}$ Molecular Biology, Sosnowiec, \\ Medical University of Silesia; ${ }^{3}$ Division of Statistics, Sosnowiec, Medical University of Silesia; \\ ${ }^{4}$ Department of Internal Medicine, Bytom, Medical University of Silesia, Katowice, Poland
}

Received July 24, 2009; Accepted September 11, 2009

DOI: 10.3892/ijmm_00000348

\begin{abstract}
Cancer is a disease of genomic instability, a multistep process involving numerous mutations and chromosomal aberrations. Telomeres are highly specialized structures at the ends of chromosomes and function to stabilize and protect the ends of linear chromosomes, therefore determining cellular immortalization. Homeostasis of telomere length is a multifactor-dependent process. Since cellular immortalization is an early and essential step towards cancer, the aim of the present study was to determine immortalization genes that are significant in colon cancer and assess their usefulness in the early diagnosis of this tumor. Expression profiles of 119 transcripts known to be involved in cellular immortalization were assessed with oligonucleotide microarrays in 13 probes of colon adenocarcinoma (low and high clinical stages) and 9 probes of controls (normal colon tissue) and were compared among these groups with the use of the Significant Analysis Microarray (SAM) software and independently verified with the effect size parameter. Eighteen genes with significantly differential expression between high clinical stage colon cancer and the control group, and 21 with differential expression between low clinical stage colon cancer and the control group were identified. Nine genes showing altered expression in both low and high clinical stage colon cancer: $A C D$ (TPP1), DKC1 and ERCC1, MYC, MAX, NBN, NOLA2, PRKDC and HSP82 should, in particular, be the subjects of further studies including QRT-PCR methods.
\end{abstract}

Correspondence to: Dr Agnieszka Witkowska, Department of Internal Medicine, Diabetology and Nephrology, Medical University of Silesia, 3 Maja 13-15, 41-800 Zabrze, Poland E-mail: witkowskaaga@op.pl

Key words: telomere, telomerase, immortalization, colon cancer, genomic instability, microarray

\section{Introduction}

Cancer is a disease of genomic instability, a multistep process involving numerous mutations and/or chromosomal aberrations (1). Chromosome instability (CIN), resulting in losses or gains of whole chromosomes or their fragments, has been observed in the majority of cancers, at the carcinoma in situ stage of carcinogenesis or even earlier (2-4). One of the neoplasms known to be CIN-based is colon cancer (5).

Most genetic aberrations, characteristic of cancers, including aneuploidy, gene amplification, loss of heterozygosity and gene loss, can be initiated by telomere dysfunction $(5,6)$. On the other hand, stability of the telomere length determines cellular immortalization, an early and esential step towards cancer (7).

Telomeres are made of tandem 5'-TTAGGG-3' repeats and a number of associated proteins responsible for their length and structure. By forming a loop structure, the very end of a telomere is protected from a DNA break, thus preventing chromosomes from end-to-end fusions, misrepair and degradation (6). This structure, called telosome (shelterin), is associated with six major proteins: TRF1, TRF2, RAP1, TIN2, POT1 and TPP1, and interacts with other proteins and DNA repair factors.

In immortal cells, loss of telomeric DNA due to degradation or incomplete replication is balanced by telomere elongation by DNA polymerase called telomerase (8), which is composed of the telomerase RNA (hTR) and the catalytic subunit, telomerase reverse transcriptase (hTERT) $(9,10)$. It is believed that telomerase is stringently repressed in normal human somatic tissues, but is reactivated in approximately $85-90 \%$ of human cancer tissues $(11,12)$. Reported data indicate the strong correlation between telomerase expression, telomere length maintenance and carcinogenesis $(13,14)$. Approximately $70 \%$ of immortalized human cell lines and $85-95 \%$ of human cancers exhibit a high expression level of hTERT (15). Yet, hTERT or telomerase appears to be insufficiently sensitive to be specific markers of carcinogenesis, particularly in telomerase-negative tumors where alternative lengthening of telomeres (ALT) occurs $(16,17)$. Indeed, telomere length homeostasis is complex and involves 
Table I. Factors involved in hTERT and hTR expression, main telomerase subunits.

\begin{tabular}{|c|c|c|c|c|}
\hline Gene symbol & Factor name & Reference & Role in transcription & Function in promoter region \\
\hline$C D K N 1 A$ & $\mathrm{p} 21$ & $(38)$ & Activator/inhibitor & Indirectly, cell cycle regulator, by MAP kinase \\
\hline$C D K N 2 A$ & p16 & $(39-41)$ & Activator/inhibitor & Indirectly, cell cycle regulator, by MAP kinase \\
\hline$E 2 F 1$ & $\mathrm{E} 2 \mathrm{~F} 1$ & $(42,43)$ & Activator/inhibitor & $\begin{array}{l}\text { Directly, transcription factor, inhibits hTERT } \\
\text { transcription in cancer, activates it in normal cells }\end{array}$ \\
\hline EGFR & EGFR & $(44,45)$ & Activator & Indirectly, by activation of ETS \\
\hline ESR1 & ER & $(46,47)$ & Activator & Directly \\
\hline ETS1 & ETS & $(48,49)$ & Activator & Directly \\
\hline HDAC9 & HDAC & $(50-52)$ & Activator & Indirectly, epigenetic regulation \\
\hline HIF $1 A$ & HIF1 & $(53)$ & Activator & Directly, mainly hTR regulation \\
\hline$I G F I R$ & IGF1R & $(45,54,55)$ & Activator & Indirectly, by IGF1 and MAP kinases \\
\hline$M A D 1 L 1$ & MAD1 & $(56)$ & Activator & Directly, complex with MAX, region E-box \\
\hline MAP3K & MAP3K & (44) & Activator/inhibitor & Indirectly, by growth factors \\
\hline$M A X$ & MAX & $(57-59)$ & Activator/inhibitor & $\begin{array}{l}\text { Directly, complex with cMYC and MAD1, } \\
\text { region E-box }\end{array}$ \\
\hline$M Y C$ & cMYC & $(57-59)$ & Activator & Directly, complex with MAX, region E-box \\
\hline$M Z F$ & & $(49)$ & Inhibitor & Directly \\
\hline NFKB1 & NFKB & $(60)$ & - & Directly \\
\hline$R B 1$ & RB1 & & Inhibitor & Indirectly, cell cycle regulator, by E2F1 factor \\
\hline$S P 1$ & SP1 & $(58,59)$ & Activator & Directly, transcription factor, region GC-box \\
\hline$S P 3$ & SP3 & $(59,61)$ & Inhibitor & Directly, transcription factor, region GC-box \\
\hline$T G F B R 2$ & TGFßR & $(45)$ & Inhibitor & Indirectly, by TGFß, cMYC \\
\hline TP53 & TP53 & $(62)$ & Inhibitor & Indirectly, cell cycle regulator, by cMYC factor \\
\hline USF1 & USF1 & $(63,64)$ & Activator & Directly \\
\hline$U S F 2$ & USF2 & $(63,64)$ & Activator & Directly, transcription factor \\
\hline WT1 & WT1 & $(65)$ & Inhibitor & Directly, transcription factor \\
\hline
\end{tabular}

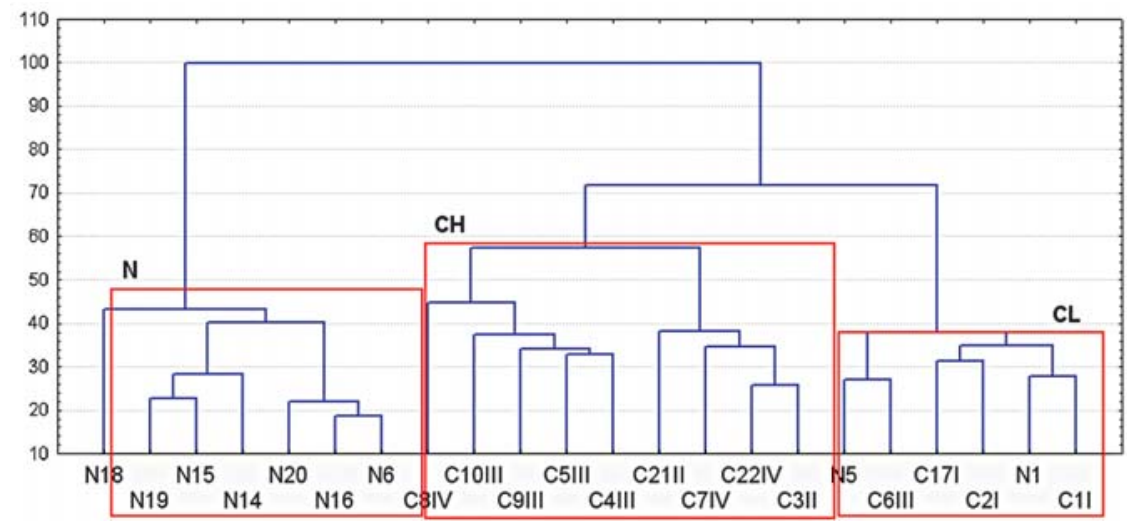

Figure 1. A dendrogram featuring clusters of transcriptoms with regard to clinical diagnosis; Ward's method. C, colon cancer; $\mathrm{CH}$, high stage colon cancer group; CL, low stage colon cancer group; N, control group. Arabic numbers, patient numbers; Roman numerals, colon cancer clinical stage.

hTR and hTERT gene amplification, regulation of their transcription (directly by transcription factors and indirectly by hormones and growth factors), epigenetic modulation, alternative splicing of hTERT, other posttranscriptional modulations of main telomerase subunits and components, regulation of telomerase complex activity, translocation of the telomerase complex, interaction of cell cycle regulators and telosome proteins (10,18-21). 
Table II. Growth factors involved in telomerase expression and regulation of its activity. ${ }^{\text {a }}$

\begin{tabular}{|c|c|c|c|c|}
\hline Gene symbol & Factor name & Effect of action & Mediator & Reference \\
\hline$T G F B 1$ & TGFß & Decreases telomerase activity & c-Myc & $(66)$ \\
\hline$E G F$ & EGF & $\begin{array}{l}\text { Increases telomerase activity in } \\
\text { telomerase-positive cells }\end{array}$ & EGFR, Ras/MEK/ERK, Ets & $(44,45,48)$ \\
\hline$I G F 1$ & IGF1 & $\begin{array}{l}\text { Increases telomerase activity in } \\
\text { prostate cancer cells }\end{array}$ & $\begin{array}{l}\text { Androgen receptor } \\
\text { Pi-3-Akt kinase cascade }\end{array}$ & $(45,54,55)$ \\
\hline$I G F B P-2$ & IGFBP-2 & $\begin{array}{l}\text { Decreases telomerase activity } \\
\text { in normal cells }\end{array}$ & & $(45,54,55)$ \\
\hline
\end{tabular}

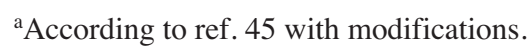

As cellular immortalization plays an important role in chromosome instability and carcinogenesis, knowledge of the mechanisms of telomere dysfunction seems crucial to understand neoplasm formation and to discover early clinical markers of cancer. The aim of the present study was to identify genes whose expression is significant in colon cancer among 70 candidate genes known to be involved in telomere homeostasis. Fig. 1 shows schematically the complex regulation of telomere stability indicating distribution, role and function of the genes analyzed in our study.

\section{Materials and methods}

Thirteen homogenates of G1-G2 colon adenocarcinoma tissue, and 9 of normal colon mucosa were obtained from patients $>50$ years of age and were histopathologically verified. Colon cancer samples were staged according to the 0-IV clinical staging scale.

Microarray methods were applied with the use of HG_U133A microchips (Affymetrix) according to the manufacturer's protocol. Normalization of microarray results was performed with the use of MicroArray Suite 5.0, R with Bioconductor modules and RMAExpress software.

The studied transcriptomes were clustered using hierarchical agglomeration (Ward's method). As shown in Fig. 1, three clusters of genetic similarity were identified. This allocation was largely compatible with histopathological diagnosis, and the dissected groups of transcriptomes were classified as high stage colon cancer ( $\mathrm{CH}$; stages II-IV), low stage colon cancer (CL; stage I and two controls), and normal colon mucosa (N; remaining controls). One stage III colon cancer transcriptom that was clustered with low stage colon cancers was classified as an outlier and excluded from further analysis.

Expression profiles of 119 transcripts (within HG_U133A microchip transcripts), known to be involved in cell immortalization processes (70 genes), were compared among the identified groups with use of the Significant Analysis Microarray (SAM) software. The 'score' and q-value parameters were estimated and verified with ES (effect size) and p-value parameters, independently.

The analyzed transcripts included factors involved in hTERT and hTR expression (Table I), growth factors engaged in telomerase expression and regulation of its
Table III. Telomerase complex factors and modulators.

\begin{tabular}{|c|c|c|}
\hline Gene symbol & Factor name & Reference \\
\hline \multicolumn{3}{|c|}{ Main telomerase subunits } \\
\hline TERC & hTR & (67) \\
\hline TERT & hTERT & (69) \\
\hline \multicolumn{3}{|c|}{ hTR subunit stabilization proteins } \\
\hline NOLAl & NOLA1 & $(10,70)$ \\
\hline NOLA2 & NOLA2 & $(10,70)$ \\
\hline NOLA3 & NOLA3 & $(10,70)$ \\
\hline$D K C 1$ & DCK1 & $(28,67)$ \\
\hline RPL22 & L22 & $(74-76)$ \\
\hline STAU1 & STAU & $(74,75)$ \\
\hline
\end{tabular}

Heterogeneous nuclear ribonucleoproteins involved in telomerase activity regulation

$\begin{array}{ll}\text { HNRPAl } & \text { hnRPA1 } \\ \text { HNRPC } & \text { hnRPC } \\ \text { HNRPD } & \text { hnRNPD }\end{array}$

Other hTERT complex proteins

$\begin{array}{ll}\text { HSP82 } & \text { HSP90 } \\ \text { HSPA9 } & \text { HSPA9B } \\ \text { LOC375931 } & \text { p23 } \\ \text { TEP1 } & \text { TEP1 } \\ \text { SMG6 } & \text { hEST1A, C17orf31 } \\ \text { SMN1 } & \text { SMN1 }\end{array}$

Phosphorylation factors of telomerase complex

$\begin{array}{ll}A K T 1 & \text { AKT } \\ P R K C B 1 & \text { PKC } \\ P P P 2 R 2 B & \text { PP2A } \\ A B L 1 & \text { c-Abl }\end{array}$

activity (Table II), the telomerase complex elements and modulators (Table III), the telosome proteins (Table IV), and proteins associated with telomeres that are involved in DNA repair pathways (Table V). 
Table IV. Telosome proteins.a

\begin{tabular}{|c|c|c|c|c|c|}
\hline $\begin{array}{l}\text { Gene } \\
\text { symbol }\end{array}$ & $\begin{array}{l}\text { Factor } \\
\text { name }\end{array}$ & Reference & $\begin{array}{l}\text { Interactions with other } \\
\text { telosome proteins }\end{array}$ & $\begin{array}{l}\text { Proposed mechanism } \\
\text { of action }\end{array}$ & $\begin{array}{c}\text { Telomere } \\
\text { dysfunction } \\
\text { when altered }\end{array}$ \\
\hline TERF1 & TRF1 & $(25,83-86)$ & $\begin{array}{l}\text { Stable part of telosome, } \\
\text { adheres to dsDNA, } \\
\text { interaction with TRF2, } \\
\text { multiple interaction with } \\
\text { other telosome proteins }\end{array}$ & $\begin{array}{l}\text { Telomere length regulation, } \\
\text { 3D structure of telomere } \\
\text { stabilization, prevent } \\
\text { telomerase access to } \\
\text { telomere }\end{array}$ & $\begin{array}{l}\text { Shortening - } \\
\text { lengthening }\end{array}$ \\
\hline TERF2 & TRF2 & $(25,86-88)$ & $\begin{array}{l}\text { Stable part of telosome, } \\
\text { adheres to dsDNA, functional } \\
\text { interaction with TRF1, } \\
\text { multiple interaction with other } \\
\text { telosome proteins mainly with } \\
\text { DNA repair system proteins }\end{array}$ & $\begin{array}{l}\text { 3D structure of telomere } \\
\text { stabilization, prevent } \\
\text { telomerase access to } \\
\text { telomere }\end{array}$ & $\begin{array}{l}\text { Shortening - } \\
\text { lengthening }\end{array}$ \\
\hline TERF $2 I P$ & RAP1 & $(72,89)$ & $\begin{array}{l}\text { Stable part of telosome, } \\
\text { interaction with TRF2 }\end{array}$ & $\begin{array}{l}\text { Negative regulator } \\
\text { of telomerase }\end{array}$ & Lengthening \\
\hline$T N K S$ & TANK1 & $(86,90-92)$ & Unstable part of telomere & $\begin{array}{l}\text { Inhibition of telomere - } \\
\text { TRF1 interaction }\end{array}$ & Shortening \\
\hline TNKS2 & TANK2 & $(91-94)$ & Unstable part of telomere & $\begin{array}{l}\text { Inhibition of telomere - } \\
\text { TRF1 interaction }\end{array}$ & - \\
\hline RIF1 & RIF1 & $(72,95)$ & $\begin{array}{l}\text { Unstable part of telomere, } \\
\text { interaction with RAP1 }\end{array}$ & $\begin{array}{l}\text { Telomere length } \\
\text { regulation }\end{array}$ & Lengthening \\
\hline POT1 & POT1 & $(96,97)$ & $\begin{array}{l}\text { Stable part of telosome, } \\
\text { adheres to ssDNA, } \\
\text { interaction with TRF1 } \\
\text { through TPP }\end{array}$ & $\begin{array}{l}\text { Stabilization/protection } \\
3 \text { " overhang, 3D structure } \\
\text { of telomere stabilization, } \\
\text { prevent telomerase access } \\
\text { to telomere, regulation of } \\
\text { telomerase activity, } \\
\text { TRF1 complex }\end{array}$ & $\begin{array}{l}\text { Shortening - } \\
\text { lengthening }\end{array}$ \\
\hline PINXI & PINX1 & (98) & $\begin{array}{l}\text { Stable part of telosome, } \\
\text { interaction with TRF1, } \\
\text { TRF2, TPP1 }\end{array}$ & $\begin{array}{l}\text { Stabilization of telomere } \\
\text { by TRF1/2 interaction } \\
\text { through TIN2, direct } \\
\text { telomerase inhibitor }\end{array}$ & Lengthening \\
\hline TINF2 & TIN2 & $(99,100)$ & $\begin{array}{l}\text { Stable part of telosome, } \\
\text { interaction with TRF1, TRF2 }\end{array}$ & $\begin{array}{l}\text { Stabilization of telomere } \\
\text { by TRF1/2, TRF1 activation }\end{array}$ & Lengthening \\
\hline$A C D$ & $\begin{array}{l}\text { TPP1, } \\
\text { PTOP, } \\
\text { TINT1 }\end{array}$ & $(19,29,101-103)$ & $\begin{array}{l}\text { Stable part of telosome, } \\
\text { interaction with TRF1, } \\
\text { POT1, TIN2 }\end{array}$ & $\begin{array}{l}\text { Stabilization of telosome, } \\
\text { 3D structure of telomere } \\
\text { stabilization, regulation } \\
\text { of telomerase activity, } \\
\text { takes part in POT1 } \\
\text { translocation toward nucleus }\end{array}$ & $\begin{array}{l}\text { Shortening - } \\
\text { lengthening }\end{array}$ \\
\hline
\end{tabular}

${ }^{\text {a} A c c o r d i n g ~ t o ~ r e f . ~} 34$ with modifications.

\section{Results}

Eighteen genes with significantly differential expression between high clinical stage colon cancer and the control group, and 21 with differential expression between low clinical stage colon cancer and controls were identified among 119 transcripts involved in immortalization processes. Table VI shows the results of the comparative analysis among the groups, with significance criteria: SAM q-value $<5 \%$, SAM score $>1.5, \mathrm{ES}>1.0$ and $\mathrm{p}<0.05(22,23)$. 
Table V. Proteins associated with telomeres that are involved in DNA repair pathways. ${ }^{\mathrm{a}}$

\begin{tabular}{|c|c|c|c|c|c|}
\hline Gene symbol & Factor name & Reference & $\begin{array}{l}\text { DNA damage } \\
\text { function }\end{array}$ & $\begin{array}{l}\text { Interaction with } \\
\text { telosome }\end{array}$ & $\begin{array}{l}\text { Telomere dysfunction } \\
\text { when altered }\end{array}$ \\
\hline ATM & ATM & $(72)$ & $\begin{array}{c}\text { Central DNA } \\
\text { damage protein }\end{array}$ & TRF2 & Shortening \\
\hline$B R C A l$ & BRCA1 & (72) & HR & TRF2 & Lengthening \\
\hline ERCCl & ERCC1/XPF & $(104)$ & NER & Multiple interaction & Formation of TDM \\
\hline MRE11A & MRN complex (MRE11) & $(36,105)$ & DSB & Multiple interaction & Shortening - lengthening \\
\hline$N B N$ & MRN complex (NBS1) & $(36,106)$ & DSB & Multiple interaction & Shortening - lengthening \\
\hline$P A R P 1$ & PARP1 & $(72)$ & BER & TRF2 & None \\
\hline$P A R P 2$ & PARP2 & $(72)$ & BER & TRF2 & None \\
\hline$P R K D C$ & DNA-PKcs & $(72)$ & NHER & Multiple interaction & Lengthening \\
\hline$R A D 50$ & MRN complex (RAD50) & $(105)$ & DSB & Multiple interaction & Shortening - lengthening \\
\hline RAD51L3 & RAD51D & $(107)$ & HR & Multiple interaction & Shortening - lengthening \\
\hline$R A D 54 L$ & RAD54 & $(108,109)$ & DSB & Multiple interaction & Shortening - lengthening \\
\hline$W R N$ & WRN & $(110,111)$ & Helicase & TRF2 & Shortening \\
\hline XRCC5 & KU80 & $(112)$ & NHER & Multiple interaction & Shortening - lengthening \\
\hline XRCC6 & KU70 & $(112)$ & NHER & Multiple interaction & Shortening - lengthening \\
\hline
\end{tabular}

${ }^{\text {a} A c c o r d i n g ~ t o ~ r e f . ~} 91$ with modifications. DSB, double strand breaks; NER, nucleotide excision repair; NHER, non-homologous excision repair; BER, base excision repair; HR, homologous repair; TDM, telomeric DNA-containing double minute chromosomes.

\section{Discussion}

Contribution of telomeres to genomic instability and their role in cellular immortalization processes are possible mechanisms leading to carcinogenesis. Telomere shortening or their dysfunction may result in cancer. On the other hand, telomere length maintenance is regarded as a necessary element of oncogenesis $(6,7)$. The analysis of the expression profile of genes involved in telomere homeostasis may help understand this paradox and discover new tools for the diagnosis and therapy of colon cancer, a model of carcinogenesis in this study.

In the present study, we demonstrated (in a semiquantitative screening method of oligonucleotide microarrays) that some of the examined transcripts involved in immortalization processes are indicative of colon cancer and are therefore candidates for markers of high or low stage colon cancer. Although the results warrant confirmation in larger study groups, they provide important knowledge of the general trends in expression profiles of immortalization factors. Our broad investigation of cellular immortalization, not only limited to main telomerase subunits but extended to other known telomere homeostasis factors, resulted in valuable findings. Figs. 2 and 3 show schematically genes whose expression was significant under the analyzed clinical conditions.

Telomerase activity and the hTERT expression level have been considered sensitive markers of cancer (yet are not specific to the type of neoplasm) $(11,12,24,25)$. Notably, in our study, hTERT expression was not a significant discriminator between the studied groups, although it has to be mentioned that the second main telomerase subunit, hTR, was not present on the microchip. Instead various other factors composing the telomerase complex appeared important in colon cancer; such as Dyscerin (DKC1), which was a strongly significant positive differentiator for both $\mathrm{CL}$ and $\mathrm{CH}$ groups vs. the control. Cohen et al (26) found that DKC1 was one of three (beside telomerase reverse transcriptase and telomerase RNA) critical components of the telomerase complex. In light of this finding, DKC1 appears to be among the most important candidates warranting further investigation. Mutations in DKC1 have been found in the rare disease, dyskeratosis congenita (27), which is also related to telomerase and telomere homeostasis dysfunction (28).

Another component of the hTR complex is NOLA2, a member of the same group of proteins as DKC1 and snoRNPs (10). Its expression was found to be significant in high stage colon cancer. It may therefore be useful in the assessment of disease progression. Other factors significant in the $\mathrm{CH}$ group were also found, such as the Hsp90 (HSP82) protein in the hTERT complex. However, strict involvement of DKC1 and NOLAs in telomerase activation (10) makes them potential markers with greater specificity.

An additional important factor, specific to telomere length maintenance, is the telosome component TPP1 (ACD1) which was a positive significant gene in both colon cancer groups in our study. TPP1 is considered a key mediator between main telosome components TRF1, TRF2 and POT1 $(19,29)$, and also, by interaction with TIN2, it stabilizes a high level conformation of telosome (30). Its increased expression 
Table VI. Transcripts of significantly different expression between low stage colon cancer and control groups (CL vs. $\mathrm{N}$ ), and between high stage colon cancer and control groups (CH vs. N), according to 'score' parameter (SAM analysis) for q-value $<0.05$.

\begin{tabular}{|c|c|c|c|}
\hline \multirow[b]{2}{*}{ Gene name } & \multirow[b]{2}{*}{ Group } & \multicolumn{2}{|c|}{ SAM score } \\
\hline & & CL vs. N & CH vs. N \\
\hline$A C D$ & $\mathrm{~T}$ & 1.460 & 3.240 \\
\hline$A K T 1$ & PH & -2.170 & \\
\hline$C D K N 1 A$ & $\mathrm{CC}$ & -2.240 & -3.410 \\
\hline$C D K N 2 A$ & $\mathrm{CC}$ & & 1.800 \\
\hline$D K C 1$ & RS & 3.240 & 3.040 \\
\hline$E G F R$ & GF & -2.190 & -3.440 \\
\hline$E R C C 1$ & $\mathrm{~T}$ & & 2.320 \\
\hline HIFIA & $\mathrm{TF}$ & 2.020 & \\
\hline$H N R P C$ & RS & 2.260 & \\
\hline$H N R P D$ & RS & 2.600 & \\
\hline HSP82 & $\mathrm{CS}$ & 2.540 & \\
\hline HSPA9 & $\mathrm{CS}$ & 2.140 & \\
\hline$I G F 1 R$ & GF & & -1.870 \\
\hline IGFBP2 & GF & 2.900 & \\
\hline$M A X$ & $\mathrm{TF}$ & -2.690 & -3.660 \\
\hline MRE11A & $\mathrm{T}$ & & 2.220 \\
\hline$M Y C$ & $\mathrm{TF}$ & 3.037 & 4.780 \\
\hline$N B N$ & $\mathrm{~T}$ & 1.910 & 1.610 \\
\hline NOLAl & RS & 2.070 & \\
\hline NOLA2 & RS & 2.710 & \\
\hline PARPI & $\mathrm{T}$ & 1.900 & \\
\hline$P R K D C$ & $\mathrm{~T}$ & 1.950 & \\
\hline RAD50 & $\mathrm{T}$ & & 1.850 \\
\hline RAD51L3 & $\mathrm{T}$ & 1.570 & 1.980 \\
\hline$R A D 54 L$ & $\mathrm{~T}$ & 2.400 & 2.950 \\
\hline$S P 1$ & $\mathrm{TF}$ & & -2.520 \\
\hline STAUI & RS & & 1.770 \\
\hline$T G F B 1$ & GF & & 1.840 \\
\hline$W T 1$ & $\mathrm{TF}$ & & 1.960 \\
\hline XRCC6 & $\mathrm{T}$ & 1.750 & \\
\hline
\end{tabular}

a'Score' indicates a rate of significance, positive values indicate overexpression of transcripts, and negative values, silencing of transcription. Groups of factors: CC, cell cycle factors; CS, catalytic hTERT subunit of telomerase; GF, growth factors; PH, phosphorylation factors; RS, RNA subunit of telomerase; T, telosome; $\mathrm{TF}$, transcription factors.

in cancer may reflect telomere disturbances resulting from chromosomal instability and makes it an attractive candidate marker of carcinogenesis.

Notable results have been obtained with some pleiotropic factors, such as cofactors c-Myc/Max, which are transcription factors of hTERT and hTR $(31,32)$. Myc was a positive significant gene in the studied colon cancer groups. It has been postulated that c-Myc acts as a transcription factor of

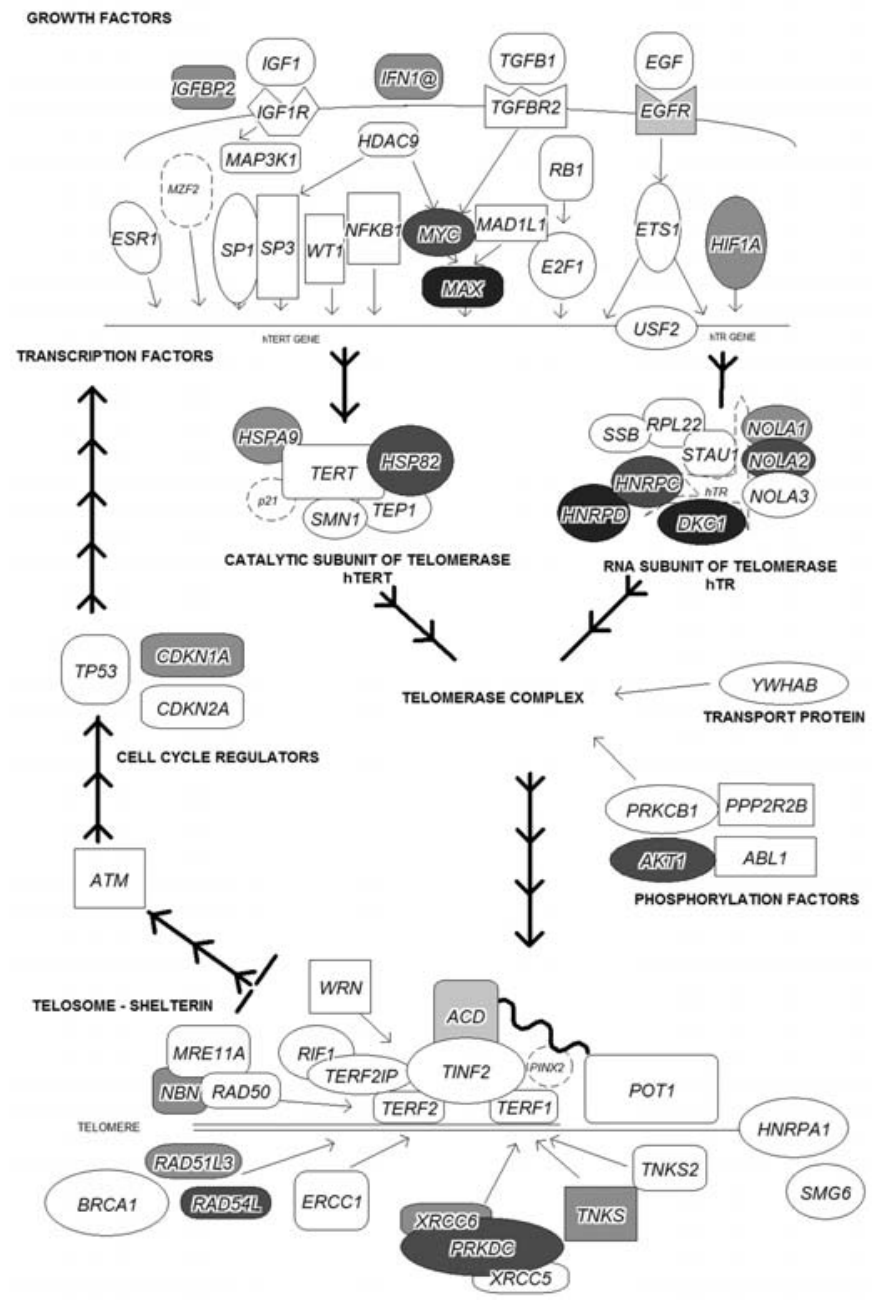

Figure 2. Transcripts differing significantly between the low stage colon cancer and control groups according to 'score' parameter (SAM analysis) for a q-value $<0.05$. Intensity of grey indicates the degree of significance. Shape of figures: oval, telomerase/telomere lengthening activator; rectangle, telomerase/telomere lengthening inhibitor; other shapes, multiple actions; dashed outline, factor not present on microchip.

many genes, but its contribution to oncogenesis is most likely through telomerase promoter activation $(31,33)$. Some authors have shown a correlation between hTERT and c-Myc overexpression in prostate (34) and cervical cancer (35). In our study, not only c-Myc overexpresssion did not correlate with higher hTERT expression level, but Max protein appeared a strong negative significant factor in both $\mathrm{CH}$ and CL groups. Is it simply a negative feedback, or rather a hallmark of more sophisticated mechanisms of Myc/Max complex regulation? It has also been suggested that the transforming activities of Myc extend beyond its ability to activate hTERT gene expression and hence telomerase activity (32). However, such strong associations with colon cancer indicate importance of these transcription factors for further investigation. The other pleiotropic factors contributing to immortalization in our study were significant DNA repair family proteins $E R C C 1, P R K D C, R A D 51 L 3, R A D 54 L$ and $N B N$. All of them interact with stable proteins of telosome. Particularly, nibrin (NBS1, NBN) warrants further analyses, due to its influence on alternate lengthening of telomeres 


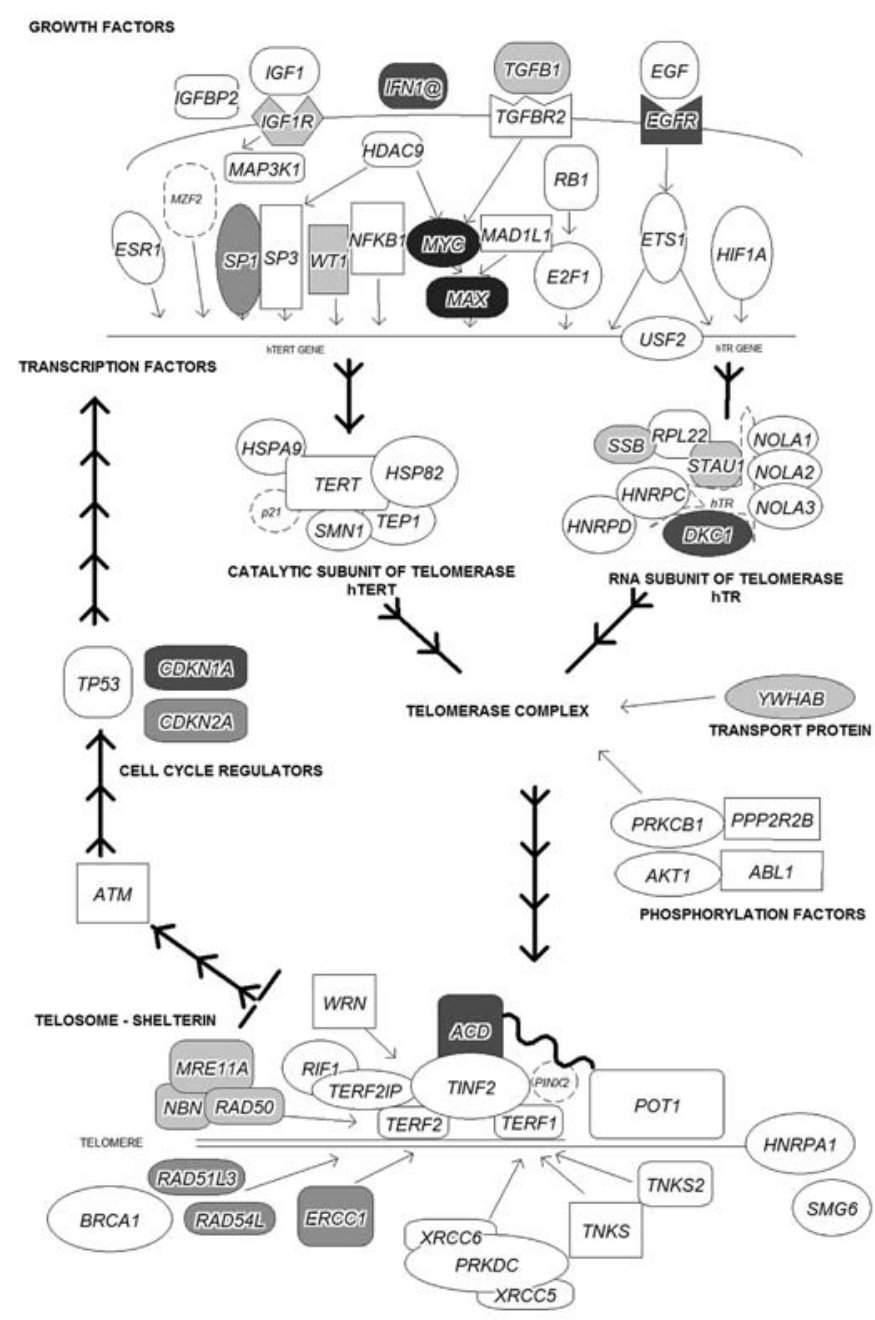

Figure 3. Transcripts differing significantly between the high stage colon cancer and control groups according to 'score' parameter (SAM analysis) for a q-value $<0.05$. Intensity of grey indicates the degree of significance. Shape of figures: oval, telomerase/telomere lengthening activator; rectangle, telomerase/telomere lengthening inhibitor; other shapes, multiple actions; dashed outline, factor not present on microchip.

(ALT) (36). ALT is independent of telomerase activation, and it is noted in approximately $10 \%$ of neoplasms $(16,17)$. The most popular hypothesis of the mechanism of ALT is homologous recombination between ends of chromosomes (37), which NBS1 is postulated to take part in. In the context of our results, NBS1 appears a significant factor with the potential for discerning cases of cancer that are based on ALT mechanisms of immortalization.

Division of the study group according to transcriptive similarity, albeit highly compatible with clinical division, imposed inclusion of two control cases in the low stage colon cancer group, which can be considered a limitation of this study. However, as these two transcriptomes came from samples of normal colon mucosa of patients with colon cancer (Fig. 1), we assumed that these two transcriptomes featured a transcriptive profile of early oncogenesis prior to morphological manifestation.

The mechanisms that induce and influence genomic instability and immortalization processes in cancer, in general and more specifically in colon cancer, are only partly under- stood. Although our data are preliminary, we believe that the knowledge gained from our study may aid in the diagnosis of cancer and the development of therapeutic tools, as well as provide a novel insight into cell immortalization processes.

\section{Acknowledgements}

The study was supported, in part, by the KBP grant NN404167234, Poland

\section{References}

1. Maser RS and DePinho RA: Connecting chromosomes, crisis, and cancer. Science 297: 565-569, 2002.

2. Lengauer C, Kinzler KW and Vogelstein B: Genetic instabilities in human cancers. Nature 396: 643-649, 1998.

3. Ried T, Heselmeyer-Haddad K, Blegen H, Schrock E and Auer G: Genomic changes defining the genesis, progression, and malignancy potential in solid human tumors: a phenotype/ genotype correlation. Genes Chromosomes Cancer 25: 195-204, 1999.

4. Moskovitz AH, Linford NJ, Brentnall TA, et al: Chromosomal instability in pancreatic ductal cells from patients with chronic pancreatitis and pancreatic adenocarcinoma. Genes Chromosomes Cancer 37: 201-206, 2003.

5. Grady WM: Genomic instability and colon cancer. Cancer Metastasis Rev 23: 11-27, 2004.

6. Cheung AL and Deng W: Telomere dysfunction, genome instability and cancer. Front Biosci 13: 2075-2090, 2008.

7. Hanahan D and Weinberg RA: The hallmarks of cancer. Cell 100: 57-70, 2000.

8. Harley CB, Futcher AB and Greider CW: Telomeres shorten during ageing of human fibroblasts. Nature 345: 458-460, 1990.

9. Wenz C, Enenkel B, Amacker M, Kelleher C, Damm K and Lingner J: Human telomerase contains two cooperating telomerase RNA molecules. EMBO J 20: 3526-3534, 2001.

10. Mergny JL, Riou JF, Mailliet P, Teulade-Fichou MP and Gilson E: Natural and pharmacological regulation of telomerase. Nucleic Acids Res 30: 839-865, 2002.

11. Kim NW, Piatyszek MA, Prowse KR, et al: Specific association of human telomerase activity with immortal cells and cancer. Science 266: 2011-2015, 1994.

12. Hiyama E and Hiyama K: Telomerase as tumor marker. Cancer Lett 194: 221-233, 2003.

13. Saldanha SN, Andrews LG and Tollefsbol TO: Assessment of telomere length and factors that contribute to its stability. Eur J Biochem 270: 389-403, 2003.

14. Shay JW and Gazdar AF: Telomerase in the early detection of cancer. J Clin Pathol 50: 106-109, 1997.

15. GeneCard for protein-coding HIF1A. Xennex, 2008.

16. Bailey SM, Brenneman MA and Goodwin EH: Frequent recombination in telomeric DNA may extend the proliferative life of telomerase-negative cells. Nucleic Acids Res 32: 3743-3751, 2004.

17. Neumann AA and Reddel RR: Telomere maintenance and cancer - look, no telomerase. Nat Rev Cancer 2: 879-884, 2002.

18. De Lange T: Shelterin: the protein complex that shapes and safeguards human telomeres. Genes Dev 19: 2100-2110, 2005.

19. Chen LY, Liu D and Songyang Z: Telomere maintenance through spatial control of telomeric proteins. Mol Cell Biol 27: 5898-5909, 2007.

20. Cong YS, Wright WE and Shay JW: Human telomerase and its regulation. Microbiol Mol Biol Rev 66: 407-425, 2002.

21. Ducrest AL, Szutorisz H, Lingner J and Nabholz M: Regulation of the human telomerase reverse transcriptase gene. Oncogene 21: 541-552, 2002.

22. Chu G: SAM, Significance Analysis of Microarrays, Users Guide and Technical Document, 2006.

23. Cohen J: Statistical Power Analysis for the Behavioral Sciences. Lawrence Earlbaum Associates, Hillsdale, NJ, 1988.

24. Shay JW and Bacchetti S: A survey of telomerase activity in human cancer. Eur J Cancer 33: 787-791, 1997.

25. Lai SR, Phipps SM, Liu L, Andrews LG and Tollefsbol TO: Epigenetic control of telomerase and modes of telomere maintenance in aging and abnormal systems. Front Biosci 10: 1779-1796, 2005 . 
26. Cohen SB, Graham ME, Lovrecz GO, Bache N, Robinson PJ and Reddel RR: Protein composition of catalytically active human telomerase from immortal cells. Science 315: 1850-1853, 2007.

27. Knight SW, Heiss NS, Vulliamy TJ, et al: X-linked dyskeratosis congenita is predominantly caused by missense mutations in the DKC1 gene. Am J Hum Genet 65: 50-58, 1999.

28. Mitchell JR, Wood E and Collins K: A telomerase component is defective in the human disease dyskeratosis congenita. Nature 402: 551-555, 1999.

29. Ye JZ, Hockemeyer D, Krutchinsky AN, et al: POT1-interacting protein PIP1: a telomere length regulator that recruits POT1 to the TIN2/TRF1 complex. Genes Dev 18: 1649-1654, 2004.

30. O'Connor MS, Safari A, Xin H, Liu D and Songyang Z: A critical role for TPP1 and TIN2 interaction in high-order telomeric complex assembly. Proc Natl Acad Sci USA 103: 11874-11879, 2006.

31. Wu KJ, Grandori C, Amacker M, et al: Direct activation of TERT transcription by c-MYC. Nat Genet 21: 220-224, 1999.

32. Greenberg RA, O'Hagan RC, Deng H, et al: Telomerase reverse transcriptase gene is a direct target of c-Myc but is not functionally equivalent in cellular transformation. Oncogene 18 : 1219-1226, 1999.

33. Takakura M, Kyo S, Kanaya T, et al: Cloning of human telomerase catalytic subunit (hTERT) gene promoter and identification of proximal core promoter sequences essential for transcriptional activation in immortalized and cancer cells. Cancer Res 59: 551-557, 1999.

34. Adaikalakoteswari A, Balasubramanyam M, Ravikumar R, Deepa R and Mohan V: Association of telomere shortening with impaired glucose tolerance and diabetic macroangiopathy. Atherosclerosis 195: 83-89, 2007.

35. Sagawa Y, Nishi H, Isaka K, Fujito A and Takayama M: The correlation of TERT expression with c-myc expression in cervical cancer. Cancer Lett 168: 45-50, 2001.

36. Zhu XD, Kuster B, Mann M, Petrini JH and de Lange T: Cellcycle-regulated association of RAD50/MRE11/NBS1 with TRF2 and human telomeres. Nat Genet 25: 347-352, 2000.

37. Dunham MA, Neumann AA, Fasching CL and Reddel RR: Telomere maintenance by recombination in human cells. Nat Genet 26: 447-450, 2000.

38. Xiang H, Wang J, Mao Y, Liu M, Reddy VN and Li DW: Human telomerase accelerates growth of lens epithelial cells through regulation of the genes mediating $\mathrm{RB} / \mathrm{E} 2 \mathrm{~F}$ pathway. Oncogene 21: 3784-3791, 2002.

39. Darbro BW, Lee KM, Nguyen NK, Domann FE and Klingelhutz AJ: Methylation of the p16(INK4a) promoter region in telomerase immortalized human keratinocytes cocultured with feeder cells. Oncogene 25: 7421-7433, 2006.

40. Tresnasari K, Takakuwa T, Ham MF, Rahadiani N, Nakajima H and Aozasa K: Telomere dysfunction and inactivation of the $\mathrm{p} 16$ (INK4a)/Rb pathway in pyothorax-associated lymphoma. Cancer Sci 98: 978-984, 2007.

41. Jacobs JJ and de Lange T: Significant role for p16INK4a in p53-independent telomere-directed senescence. Curr Biol 14: 2302-2308, 2004.

42. Alonso MM, Fueyo J, Yung WK and Gomez-Manzano C: E2F1 and telomerase: alliance in the dark side. Cell Cycle 5: 930-935, 2006.

43. Crowe DL and Nguyen DC: Rb and E2F-1 regulate telomerase activity in human cancer cells. Biochim Biophys Acta 1518: 1-6, 2001.

44. Budiyanto A, Bito T, Kunisada M, Ashida M, Ichihashi M and Ueda M: Inhibition of the epidermal growth factor receptor suppresses telomerase activity in HSC-1 human cutaneous squamous cell carcinoma cells. J Invest Dermatol 121: 1088-1094, 2003.

45. Bayne S and Liu JP: Hormones and growth factors regulate telomerase activity in ageing and cancer. Mol Cell Endocrinol 240: 11-22, 2005.

46. Misiti S, Nanni S, Fontemaggi G, et al: Induction of hTERT expression and telomerase activity by estrogens in human ovary epithelium cells. Mol Cell Biol 20: 3764-3771, 2000.

47. Lopatina NG, Poole JC, Saldanha SN, et al: Control mechanisms in the regulation of telomerase reverse transcriptase expression in differentiating human teratocarcinoma cells. Biochem Biophys Res Commun 306: 650-659, 2003.

48. Maida Y, Kyo S, Kanaya T, et al: Direct activation of telomerase by EGF through Ets-mediated transactivation of TERT via MAP kinase signaling pathway. Oncogene 21: 4071-4079, 2002.
49. Cairney CJ and Keith WN: Telomerase redefined: integrated regulation of hTR and hTERT for telomere maintenance and telomerase activity. Biochimie 90: 13-23, 2008.

50. Lee H, Sengupta N, Villagra A, Rezai-Zadeh N and Seto E: Histone deacetylase 8 safeguards the human ever-shorter telomeres 1B (hEST1B) protein from ubiquitin-mediated degradation. Mol Cell Biol 26: 5259-5269, 2006.

51. Mukhopadhyay NK, Gordon GJ, Maulik G, et al: Histone deacetylation is directly involved in desilencing the expression of the catalytic subunit of telomerase in normal lung fibroblast. J Cell Mol Med 9: 662-669, 2005.

52. Wu P, Meng L, Wang H, et al: Role of hTERT in apoptosis of cervical cancer induced by histone deacetylase inhibitor. Biochem Biophys Res Commun 335: 36-44, 2005.

53. Zhao JQ, Hoare SF, McFarlane R, et al: Cloning and characterization of human and mouse telomerase RNA gene promoter sequences. Oncogene 16: 1345-1350, 1998.

54. Wetterau LA, Francis MJ, Ma L and Cohen P: Insulin-like growth factor I stimulates telomerase activity in prostate cancer cells. J Clin Endocrinol Metab 88: 3354-3359, 2003.

55. Moore MG, Wetterau LA, Francis MJ, Peehl DM and Cohen P: Novel stimulatory role for insulin-like growth factor binding protein-2 in prostate cancer cells. Int J Cancer 105: 14-19, 2003.

56. Oh S, Song YH, Yim J and Kim TK: Identification of Mad as a repressor of the human telomerase (hTERT) gene. Oncogene 19: 1485-1490, 2000.

57. Wang J, Xie LY, Allan S, Beach D and Hannon GJ: Myc activates telomerase. Genes Dev 12: 1769-1774, 1998

58. Kyo S, Takakura M, Taira T, et al: Sp1 cooperates with c-Myc to activate transcription of the human telomerase reverse transcriptase gene (hTERT). Nucleic Acids Res 28: 669-677, 2000.

59. Poole JC, Andrews LG and Tollefsbol TO: Activity, function, and gene regulation of the catalytic subunit of telomerase (hTERT). Gene 269: 1-12, 2001.

60. Yin L, Hubbard AK and Giardina C: NF-kappa B regulates transcription of the mouse telomerase catalytic subunit. J Biol Chem 275: 36671-36675, 2000 .

61. Wooten LG and Ogretmen B: Sp1/Sp3-dependent regulation of human telomerase reverse transcriptase promoter activity by the bioactive sphingolipid ceramide. J Biol Chem 280: 28867-28876, 2005.

62. Kanaya T, Kyo S, Hamada K, et al: Adenoviral expression of p53 represses telomerase activity through down-regulation of human telomerase reverse transcriptase transcription. Clin Cancer Res 6: 1239-1247, 2000.

63. Goueli BS and Janknecht R: Regulation of telomerase reverse transcriptase gene activity by upstream stimulatory factor. Oncogene 22: 8042-8047, 2003.

64. Yago M, Ohki R, Hatakeyama S, Fujita T and Ishikawa F: Variant forms of upstream stimulatory factors (USFs) control the promoter activity of hTERT, the human gene encoding the catalytic subunit of telomerase. FEBS Lett 520: 40-46, 2002.

65. Oh S, Song Y, Yim J and Kim TK: The Wilms' tumor 1 tumor suppressor gene represses transcription of the human telomerase reverse transcriptase gene. J Biol Chem 274: 37473-37478, 1999.

66. Yang H, Kyo S, Takatura M and Sun L: Autocrine transforming growth factor beta suppresses telomerase activity and transcription of human telomerase reverse transcriptase in human cancer cells. Cell Growth Differ 12: 119-127, 2001.

67. Chang JT, Chen YL, Yang HT, Chen CY and Cheng AJ Differential regulation of telomerase activity by six telomerase subunits. Eur J Biochem 269: 3442-3450, 2002.

68. Akalin A, Elmore LW, Forsythe HL, et al: A novel mechanism for chaperone-mediated telomerase regulation during prostate cancer progression. Cancer Res 61: 4791-4796, 2001.

69. Nakamura TM, Morin GB, Chapman KB, et al: Telomerase catalytic subunit homologs from fission yeast and human. Science 277: 955-959, 1997

70. Pogacic V, Dragon F and Filipowicz W: Human H/ACA small nucleolar RNPs and telomerase share evolutionarily conserved proteins NHP2 and NOP10. Mol Cell Biol 20: 9028-9040, 2000.

71. Reichenbach P, Hoss M, Azzalin CM, Nabholz M, Bucher P and Lingner J: A human homolog of yeast Est1 associates with telomerase and uncaps chromosome ends when overexpressed. Curr Biol 13: 568-574, 2003.

72. Raynaud CM, Sabatier L, Philipot O, Olaussen KA and Soria JC: Telomere length, telomeric proteins and genomic instability during the multistep carcinogenic process. Crit Rev Oncol Hematol 66: 99-117, 2008. 
73. Bachand F, Boisvert FM, Cote J, Richard S and Autexier C: The product of the survival of motor neuron (SMN) gene is a human telomerase-associated protein. Mol Biol Cell 13: 3192-3202, 2002.

74. Le S, Sternglanz R and Greider CW: Identification of two RNAbinding proteins associated with human telomerase RNA. Mol Biol Cell 11: 999-1010, 2000

75. Bachand F, Triki I and Autexier C: Human telomerase RNAprotein interactions. Nucleic Acids Res 29: 3385-3393, 2001.

76. Ford LP, Shay JW and Wright WE: The La antigen associates with the human telomerase ribonucleoprotein and influences telomere length in vivo. RNA 7: 1068-1075, 2001.

77. Kang SS, Kwon T, Kwon DY and Do SI: Akt protein kinase enhances human telomerase activity through phosphorylation of telomerase reverse transcriptase subunit. J Biol Chem 274: 13085-13090, 1999.

78. Ford LP, Suh JM, Wright WE and Shay JW: Heterogeneous nuclear ribonucleoproteins $\mathrm{C} 1$ and $\mathrm{C} 2$ associate with the RNA component of human telomerase. Mol Cell Biol 20: 9084-9091, 2000.

79. Ku WC, Cheng AJ and Wang TC: Inhibition of telomerase activity by PKC inhibitors in human nasopharyngeal cancer cells in culture. Biochem Biophys Res Commun 241: 730-736, 1997.

80. Ford LP, Wright WE and Shay JW: A model for heterogeneous nuclear ribonucleoproteins in telomere and telomerase regulation. Oncogene 21: 580-583, 2002.

81. Li H, Zhao LL, Funder JW and Liu JP: Protein phosphatase 2A inhibits nuclear telomerase activity in human breast cancer cells. J Biol Chem 272: 16729-16732, 1997.

82. Kharbanda S, Kumar V, Dhar S, et al: Regulation of the hTERT telomerase catalytic subunit by the c-Abl tyrosine kinase. Curr Biol 10: 568-575, 2000.

83. Van Steensel B and de Lange T: Control of telomere length by the human telomeric protein TRF1. Nature 385: 740-743, 1997.

84. Broccoli D, Smogorzewska A, Chong L and de Lange T: Human telomeres contain two distinct Myb-related proteins, TRF1 and TRF2. Nat Genet 17: 231-235, 1997.

85. Zhong Z, Shiue L, Kaplan S and de Lange T: A mammalian factor that binds telomeric TTAGGG repeats in vitro. Mol Cell Biol 12: 4834-4843, 1992.

86. Smogorzewska A and de Lange T: Regulation of telomerase by telomeric proteins. Annu Rev Biochem 73: 177-208, 2004.

87. Stansel RM, de Lange T and Griffith JD: T-loop assembly in vitro involves binding of TRF 2 near the $3^{\prime}$ telomeric overhang. EMBO J 20: 5532-5540, 2001.

88. Van Steensel B, Smogorzewska A and de Lange T: TRF2 protects human telomeres from end-to-end fusions. Cell 92: 401-413, 1998.

89. Li B, Oestreich $\mathrm{S}$ and de Lange T: Identification of human Rap1: implications for telomere evolution. Cell 101: 471-483, 2000.

90. Kim SH, Kaminker P and Campisi J: TIN2, a new regulator of telomere length in human cells. Nat Genet 23: 405-412, 1999.

91. Smith S and de Lange T: Tankyrase promotes telomere elongation in human cells. Curr Biol 10: 1299-1302, 2000.

92. Cook BD, Dynek JN, Chang W, Shostak G and Smith S: Role for the related poly(ADP-Ribose) polymerases tankyrase 1 and 2 at human telomeres. Mol Cell Biol 22: 332-342, 2002.

93. Smith S, Giriat I, Schmitt A and de Lange T: Tankyrase, a poly(ADP-ribose) polymerase at human telomeres. Science 282 : 1484-1487, 1998.
94. Sbodio JI, Lodish HF and Chi NW: Tankyrase-2 oligomerizes with tankyrase-1 and binds to both TRF1 (telomere-repeatbinding factor 1) and IRAP (insulin-responsive aminopeptidase). Biochem J 361: 451-459, 2002.

95. Silverman J, Takai H, Buonomo SB, Eisenhaber F and de Lange T: Human Rif1, ortholog of a yeast telomeric protein, is regulated by ATM and 53BP1 and functions in the S-phase checkpoint. Genes Dev 18: 2108-2119, 2004.

96. Colgin LM, Baran K, Baumann P, Cech TR and Reddel RR: Human POT1 facilitates telomere elongation by telomerase. Curr Biol 13: 942-946, 2003.

97. Kelleher C, Kurth I and Lingner J: Human protection of telomeres 1 (POT1) is a negative regulator of telomerase activity in vitro. Mol Cell Biol 25: 808-818, 2005.

98.Zhou XZ and Lu KP: The Pin2/TRF1-interacting protein PinX1 is a potent telomerase inhibitor. Cell 107: 347-359, 2001.

99. Kim SH, Beausejour C, Davalos AR, Kaminker P, Heo SJ and Campisi J: TIN2 mediates functions of TRF2 at human telomeres. J Biol Chem 279: 43799-43804, 2004.

100. Ye JZ, Donigian JR, van Overbeek M, et al: TIN2 binds TRF1 and TRF2 simultaneously and stabilizes the TRF2 complex on telomeres. J Biol Chem 279: 47264-47271, 2004.

101. Xin H, Liu D, Wan M, et al: TPP1 is a homologue of ciliate TEBP-beta and interacts with POT1 to recruit telomerase. Nature 445: 559-562, 2007.

102. Houghtaling BR, Cuttonaro L, Chang W and Smith S: A dynamic molecular link between the telomere length regulator TRF1 and the chromosome end protector TRF2. Curr Biol 14: 1621-1631, 2004.

103.Liu D, Safari A, O'Connor MS, et al: PTOP interacts with POT1 and regulates its localization to telomeres. Nat Cell Biol 6: 673-680, 2004.

104.Zhu XD, Niedernhofer L, Kuster B, Mann M, Hoeijmakers JH and de Lange T: ERCC1/XPF removes the 3 ' overhang from uncapped telomeres and represses formation of telomeric DNA-containing double minute chromosomes. Mol Cell 12: 1489-1498, 2003.

105. Brunori M, Luciano P, Gilson E and Geli V: The telomerase cycle: normal and pathological aspects. J Mol Med 83: 244-257, 2005.

106. Yeager TR, Neumann AA, Englezou A, Huschtscha LI, Noble JR and Reddel RR: Telomerase-negative immortalized human cells contain a novel type of promyelocytic leukemia (PML) body. Cancer Res 59: 4175-4179, 1999.

107. Tarsounas M, Munoz P, Claas A, et al: Telomere maintenance requires the RAD51D recombination/repair protein. Cell 117: 337-347, 2004

108. Akiyama K, Yusa K, Hashimoto H, et al: Rad54 is dispensable for the ALT pathway. Genes Cells 11: 1305-1315, 2006.

109. Jaco I, Munoz P, Goytisolo F, et al: Role of mammalian Rad54 in telomere length maintenance. Mol Cell Biol 23: 5572-5580, 2003.

110. Opresko PL, von Kobbe C, Laine JP, Harrigan J, Hickson ID and Bohr VA: Telomere-binding protein TRF2 binds to and stimulates the Werner and Bloom syndrome helicases. J Biol Chem 277: 41110-41119, 2002.

111. Machwe A, Xiao L and Orren DK: TRF2 recruits the Werner syndrome (WRN) exonuclease for processing of telomeric DNA. Oncogene 23: 149-156, 2004.

112. Hsu HL, Gilley D, Galande SA, et al: Ku acts in a unique way at the mammalian telomere to prevent end joining. Genes Dev 14: 2807-2812, 2000. 